\title{
AGRICULTURAL DROUGHT INVESTIGATION OF NORTHERN THAILAND USING GENERALIZED MONSOON INDEX
}

\author{
Phumkokrux N*, Sirito S, Klaynadda S and Sonsri P \\ Department of Geography, Faculty of Education, Ramkhamhaeng University. Bangkok. Thailand
}

\begin{abstract}
This research aims to study a change of rainfall and indicate levels of agricultural drought in the Southwest monsoon period of the northern region of Thailand by using the GMI. The rainfall data from June to September of the year 1987 to 2019 were collected from 21 meteorological stations over the northern region of Thailand. The data were used to create the maps of agricultural drought levels and to analyze the distribution of agricultural drought on the study period. Then, the distribution of total rainfall maps of each month and the trend of rainfall over the past 33 years were examined. The results showed that agricultural drought in Northern Thailand had no exact pattern. However, there was a drought impact on crops level in the lower part of Northern Thailand at the end of the Southwest monsoon period in 2019 with the GMI percentile score average (GMIpct ${ }_{\mathrm{sw}}$ ) of $22.82 \%$. Furthermore, the severe drought impact and possible crop failure level were observed in the upper part of Northern Thailand in the same period. Moreover, the total rainfall sharply increased from June to August then decreased in September. The trend of total rainfall of the Southwest monsoon period (June to September) fluctuates along the study period with average value of 796.67 millimeter.
\end{abstract}

Keywords: Agricultural drought; Drought in Thailand; Generalized Monsoon Index; Rainfall change

\section{Introduction}

Drought is a natural hazard which Thailand have to face with many years. The drought situation impacts on any activities of people, community, agriculture and forest situation in many areas of Thailand. (Luedi, 2016) However, northern Thailand is located at $98.99 \mathrm{~N}-99.95 \mathrm{~N}$ and $97.33 \mathrm{E}$ 101.79 E (decimal degrees) covered 15 provinces (Thai meteorological department, 2019) and this region has a variety of topography types such as plain, floodplain, mountains, and valley. Moreover, the Koppen climate type of this region is tropical wet and dry climate (Aw) which has 3 seasons (summer in February to May, rainy in June to September and winter in October to January). The dry season can become severe, and often drought conditions prevail during the course of the year. (CTN News, 2019) Furthermore, main occupation of people in northern areas is agriculturist and there are agricultural areas about $21.8 \%$ of the total of agricultural area in Thailand (Office of national economic and social development council, 2020). These reasons bring northern Thailand has many types of agriculture such as Paddy field, Field crops, Flower farm, etc. (Office of Agricultural Economics, , 2019; CARE/HRIP, 1994). Moreover, the most of agricultural season usually under Southwest monsoon period thus, water situation for agriculture is necessary to monitor in this region. Therefore, the drought situation can impact on agriculture and affect to main income of the people in this region. 
From all problems mentioned above bring authors to the objectives of this study which are; (1) to study a change of rainfall and its trend in northern Thailand and (2) to monitor agricultural drought situation and indicate levels of agricultural drought in the Southwest monsoon period of the northern region by using the Generalized Monsoon Index or GMI over 33 years past. The results of this study can be an evidence that Thailand is facing with climate change and global warming problems.

\section{Objectives}

1. To study a change of rainfall and its trend in Northern Thailand.

2. To monitor agricultural drought situation and indicate levels of agricultural drought in the Southwest monsoon period of the northern region by using the Generalized Monsoon Index or GMI

\section{Materials and Methods}

\section{Study area}

The study area which using in this study included 21 meteorological stations covered $\mathbf{1 5}$ provinces around Northern Thailand as shown in the table1 and figure 1. (Thai meteorological department, 2019)

Table 1: Meteorological stations in Northern Thailand. (Thai meteorological department, 2012)

\begin{tabular}{llllll}
\hline No. & Station No. & Station name & Province & Latitude & Longitude \\
\hline 1 & 48300 & Mae Hong Son & Mae Hong Son & $19^{\circ} 18^{\prime}$ & $97^{\circ} 50^{\prime}$ \\
\hline 2 & 48303 & Chiang Rai & Chiang Rai & $19^{\circ} 58^{\prime}$ & $99^{\circ} 53^{\prime}$ \\
\hline 3 & 48307 & Thung Chang & Nan & $19^{\circ} 24^{\prime}$ & $100^{\circ} 52^{\prime}$ \\
\hline 4 & 48310 & Phayao & Phayao & $19^{\circ} 08^{\prime}$ & $99^{\circ} 54^{\prime}$ \\
\hline 5 & 48315 & Tha Wang Pha & Nan & $19^{\circ} 07^{\prime}$ & $100^{\circ} 48^{\prime}$ \\
\hline 6 & 48325 & Mae Sariang & Mae Hong Son & $18^{\circ} 10^{\prime}$ & $97^{\circ} 56^{\prime}$ \\
\hline 7 & 48327 & Chiang Mai & Chiang Mai & $18^{\circ} 47^{\prime}$ & $98^{\circ} 59^{\prime}$ \\
\hline 8 & 48328 & Lampang & Lampang & $18^{\circ} 17^{\prime}$ & $99^{\circ} 31^{\prime}$ \\
\hline 9 & 48329 & Lamphun & Lamphun & $18^{\circ} 34^{\prime}$ & $99^{\circ} 02^{\prime}$ \\
\hline 10 & 48330 & Phrae & Phrae & $18^{\circ} 10^{\prime}$ & $100^{\circ} 10^{\prime}$ \\
\hline 11 & 48331 & Nan & Nan & $18^{\circ} 47^{\prime}$ & $100^{\circ} 47^{\prime}$ \\
\hline 12 & 48351 & Uttaradit & Uttaradit & $17^{\circ} 37^{\prime}$ & $100^{\circ} 06^{\prime}$ \\
\hline 13 & 48374 & Lom Sak & Phetchabun & $16^{\circ} 46^{\prime}$ & $101^{\circ} 15^{\prime}$ \\
\hline 14 & 48375 & Mae Sot & Tak & $16^{\circ} 40^{\prime}$ & $98^{\circ} 33^{\prime}$ \\
\hline 15 & 48376 & Tak & Tak & $16^{\circ} 53^{\prime}$ & $99^{\circ} 07^{\prime}$ \\
\hline 16 & 48377 & Bhumibol Dam & Tak & $17^{\circ} 14^{\prime}$ & $99^{\circ} 03^{\prime}$ \\
\hline 17 & 48378 & Phitsanulok & Phitsanulok & $16^{\circ} 47^{\prime}$ & $100^{\circ} 16^{\prime}$ \\
\hline 18 & 48379 & Phetchabun & Phetchabun & $16^{\circ} 26^{\prime}$ & $101^{\circ} 09^{\prime}$ \\
\hline 19 & 48380 & Kamphaeng Phet & Kamphaeng Phet & $16^{\circ} 29^{\prime}$ & $99^{\circ} 32^{\prime}$ \\
\hline 20 & 48385 & Umphang & Wichian Buri & $16^{\circ} 01^{\prime}$ & $98^{\circ} 52^{\prime}$ \\
\hline 21 & 48413 & Phetchabun & $15^{\circ} 39^{\prime}$ & $101^{\circ} 07^{\prime}$ \\
\hline
\end{tabular}




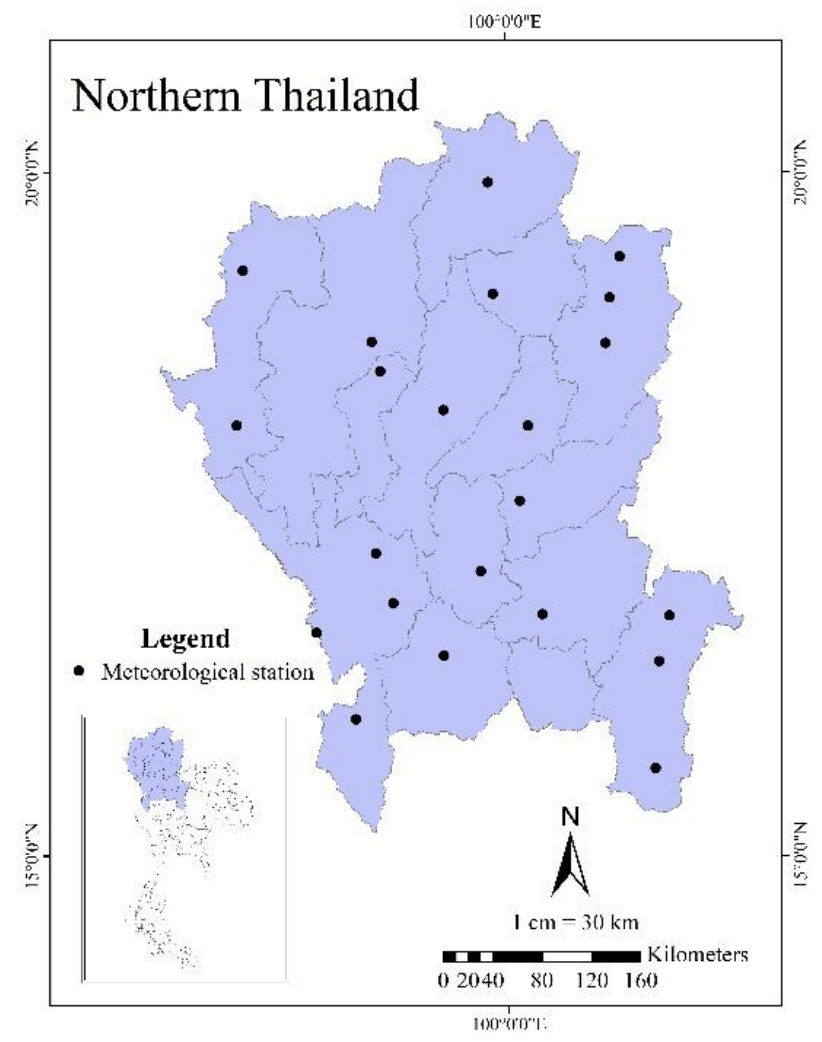

Figure 1: Study area

\section{Adequacy investigation of meteorological stations}

The objective of adequacy investigation of meteorological stations is for checking the number of meteorological stations which can represent of rainfall data collection in northern Thailand. Therefore, $C_{v}$ method (Wichitarapongsakun, 2016). is the suitable method to use in this study to check the adequacy investigation of meteorological station. The equations of this method are shown below

$\mathrm{N}=\left(\mathrm{C}_{\mathrm{v}} / \varepsilon\right)^{2}$

$\mathrm{C}_{v}=\left(100 \sigma_{\mathrm{m}-1}\right) / \overline{\mathrm{P}}$

$\sigma_{\mathrm{m}-1}=\left\{\left[\Sigma^{\mathrm{m}}{ }_{1}\left(\mathrm{P}_{\mathrm{i}}-\overline{\mathrm{P}}\right)^{2}\right] /(\mathrm{m}-1)\right\}^{1 / 2}$

Whereas $\mathrm{N}$ is the suitable number of meteorological stations. $\mathrm{C}_{\mathrm{v}}$ is rainfall coefficient coefficient of $\mathrm{m}$ stations. $\varepsilon$ is the percentage of allowable errors in the estimation. The estimation of average of rainfall data determine $\varepsilon=10 \%$ by the suggestion of world meteorological organization: WMO (Subramanya, 2008). $\sigma$ is standard deviation of the data of rainfall from $m$ stations. $\overline{\mathrm{P}}$ is the average of rainfall data from $\mathrm{m}$ stations. and $\mathrm{P}_{\mathrm{i}}$ is the rainfall data which was collected from any stations $(\mathrm{i}=1,2,3, \ldots, \mathrm{m})$

\section{Rainfall change and its trends monitoring}

The total rainfall data from 21 meteorological stations which covered Northern Thailand, of June to September of 1987 - 2019 were used in this study to create the total rainfall distribution maps under 
SW monsoon period by using raster interpolation method (Kriging) to monitor how the rainfall in Northern Thailand changes. The data were collected by Thai meteorological department. Line graph of trend of total rainfall in SW period of Northern Thailand by months and trend of total rainfall in SW monsoon period of Northern Thailand were created by excel program to monitor the trend of rainfall change in the study area

\section{Generalized Monsoon Index (GMI) analysis}

Agricultural Drought can be investigated by Generalized Monsoon Index or GMI which is developed by Yield Monsoon Index (YMI) in 1982 (Achutuni, Steyaert and Sakimoto, 1982) to illustrate and monitor the drought affect plants in every growing step in monsoon period. The most of planting season in Thailand is under Southwest Monsoon or SW period which affect to Thailand around June to September. Therefore, GMI can be analysed to understand health of plants in SW period by gathering monthly rainfall data of each station in the study area. (Thai meteorological department, 2012)

$$
\begin{aligned}
& \text { GMI6 }=\mathbf{0 . 1 2 5} \mathrm{P6} \\
& \text { GMI7 }=\mathbf{0 . 1 2 5} \mathrm{P} 6+\mathbf{0 . 1 2 5} \mathrm{P} 7 \\
& \text { GMI8 }=\mathbf{0 . 1 2 5} \mathrm{P} 6+\mathbf{0 . 1 2 5} \mathrm{P} 7+\mathbf{0 . 5} \mathrm{P} 8 \\
& \text { GMI9 }=0.125 \mathrm{P} 6+0.125 \mathrm{P} 7+0.5 \mathrm{P} 8+0.25 \mathrm{P} 9
\end{aligned}
$$

Whereas; GMI6 refer to P6 is total monthly rainfall of June, P7 is total monthly rainfall of July, P8 is total monthly rainfall of August and P9 is total monthly rainfall of September.

Therefore, the agricultural drought in the end of southwest monsoon period (June to September) can investigate by the equation below,

$$
\text { GMIsw }=0.125 \mathrm{P} 6+0.125 \mathrm{P} 7+0.5 \mathrm{P} 8+0.25 \mathrm{P} 9
$$

$\mathrm{GMI}_{\mathrm{sw}}$ of each meteorological station which was calculated from the equation (5), is shown in millimeter. However; it is so hard to identify the drought impact and determine criteria of plants health. Therefore, $\mathrm{GMI}_{\mathrm{sw}}$ can be transfer to percentile rank of each meteorological station by the equation (9) and the criteria which was used to consider plants health is illustrated in the table 2.

$\mathrm{GMI}_{\mathrm{pct}}=(\mathrm{r} \times 100) /(\mathrm{n}+1)$

Whereas; $\mathrm{GMI}_{\mathrm{pct}}$ refer to percentile rank of GMI of each meteorological station in the end of southwest monsoon period, $r$ is rank of GMI in each year of each meteorological station, $n$ is number of years which the data was gathered in each meteorological station. 
Table 2: The criteria which was used to consider plants health (Wichitarapongsakun, 2016)

\begin{tabular}{lll}
\hline GMI $_{\text {pct }}$ & Level of drought & Plants health \\
\hline $0-20$ & 6 & severe drought impact and possible crop failure \\
\hline $21-30$ & 5 & drought impact on crops \\
\hline $31-40$ & 4 & moderate drought impact on crops \\
\hline $41-60$ & 3 & normal crops condition \\
\hline $61-90$ & 2 & possible above normal crops \\
\hline $91-100$ & 1 & possible excessive moisture \\
\hline
\end{tabular}

\section{Results}

\section{Adequacy investigation of meteorological stations}

The suitable number of meteorological stations which checked by $\mathrm{C}_{\mathrm{v}}$ method is 9 stations, which calculated by equation (1). Thus, 21 meteorological stations which using in this study is suitable for represent the rainfall data in northern Thailand.

\section{Rainfall change and its trends}

Southwest Monsoon period of Thailand starts from June to September of every years. Therefore, the total of rainfall in SW period are presented in figure 2. The maps are illustrated that there is no certain pattern which how total rainfall changed. The total rainfall in SW period is significantly lower in 1987, 1990, 1993, 1998, 2015 and 2019 especially, the central of Northern Thailand. In contrast, the total of rainfall is remarkably higher in 1994, 1995, 2005, 2010, 2011 and 2013 especially, the upper and round of Northern Thailand. From the figure 3(A), the trend of total rainfall in June, July, August and September of Northern Thailand from 1987 to 2019 were analysed by excel program. The trend of rainfall gradually increased from June and hit the peak at August then, its gradually decreased in September in every year. However, the trend of total rainfall in SW period of Northern Thailand was fluctuated with the total rainfall averaging at 796.67 millimeters and standard deviation at 110.36. Moreover, the total rainfall decreased by 0.1527 millimeter per year as shown in the figure 3(B).

\section{Agricultural Drought analysis by Generalized Monsoon Index}

Agricultural Drought in Northern Thailand in SW period was analysed by Generalized Monsoon Index $\left(\mathrm{GMI}_{\mathrm{sw}}\right)$. From the figure 4, the maps were presented GMI Percentile rank after finishing Southwest Monsoon period over 33 years past. The level of agricultural drought is presented in table 2. The agricultural drought characteristics in the most area of Northern Thailand was in drought impact on crops level and severe drought impact and possible crop failure level in 1989, 1990, 1993, 1997, 1998, 1999, 2007, 2015, 2018 and 2019. Moreover, the most years which Northern Thailand faced to extreme agricultural drought such as 1989, 1990, 1993, 2015 and 2019, was agreeable with the total rainfall data which illustrated in the maps figure 2 . 

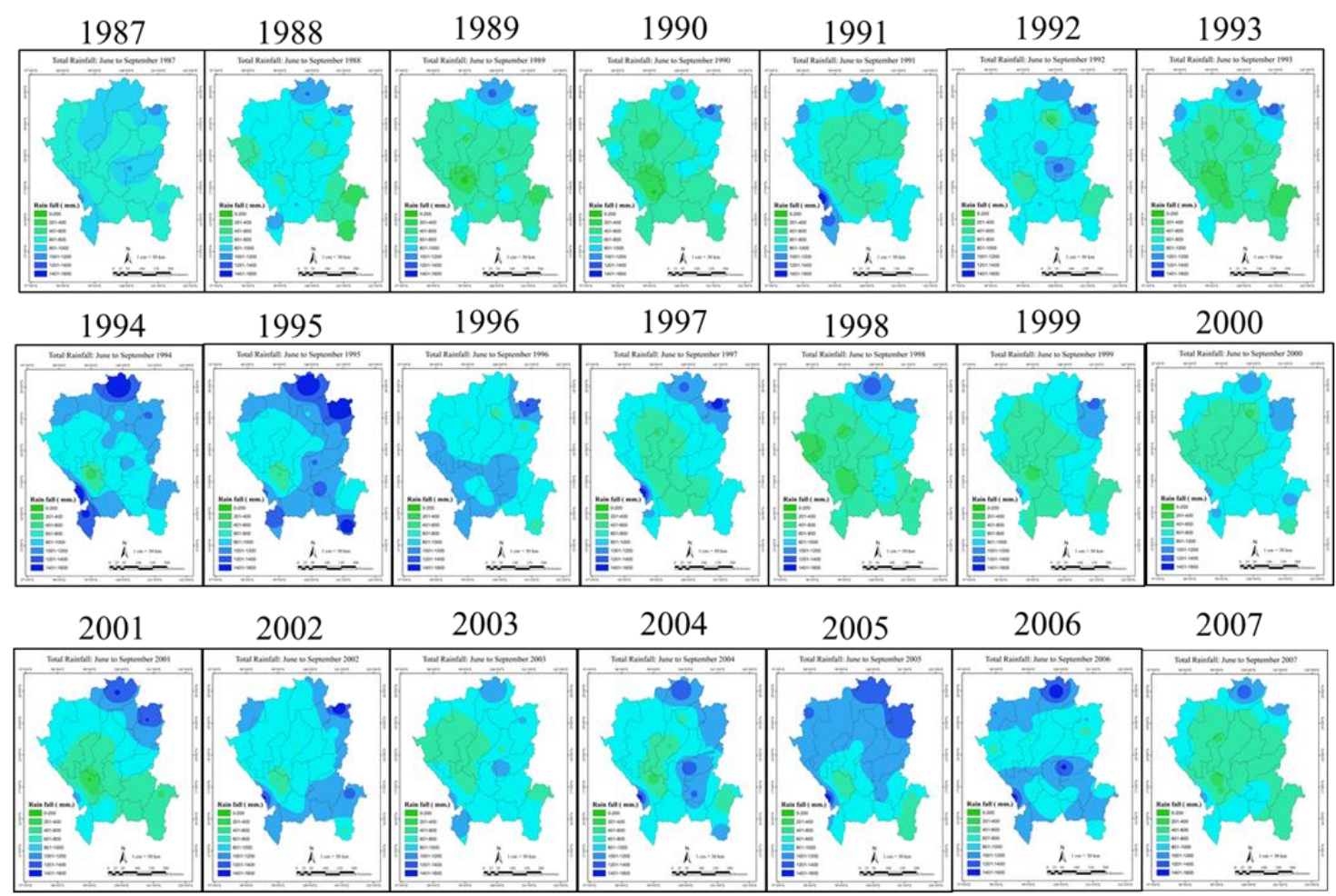

\begin{tabular}{|l|l|l|l|l|l|l|}
\hline \multicolumn{2}{l|}{2008} & 2009 & 2010 & 2011 & 2012 & 2013 \\
\hline
\end{tabular}
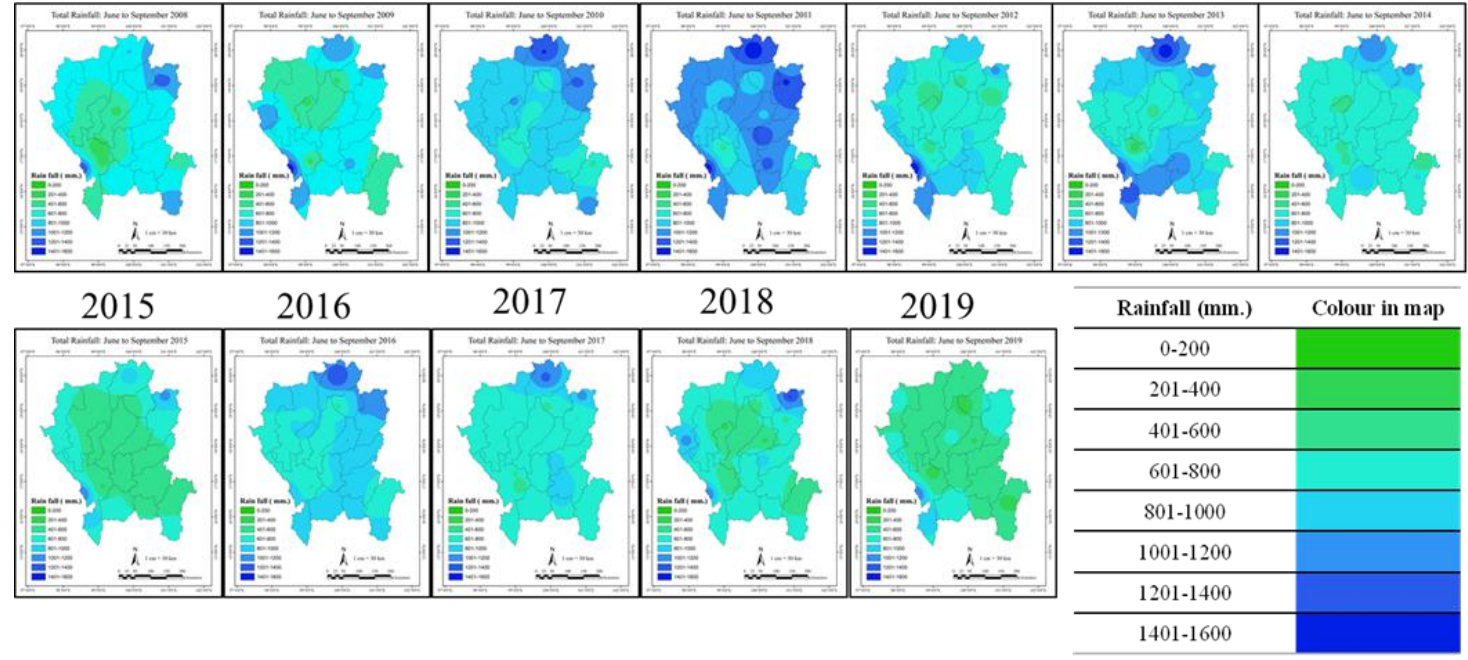

Figure 2: Distribution of total rainfall in Northern, Thailand during Southwest Monsoon period of 1987 to 2019 


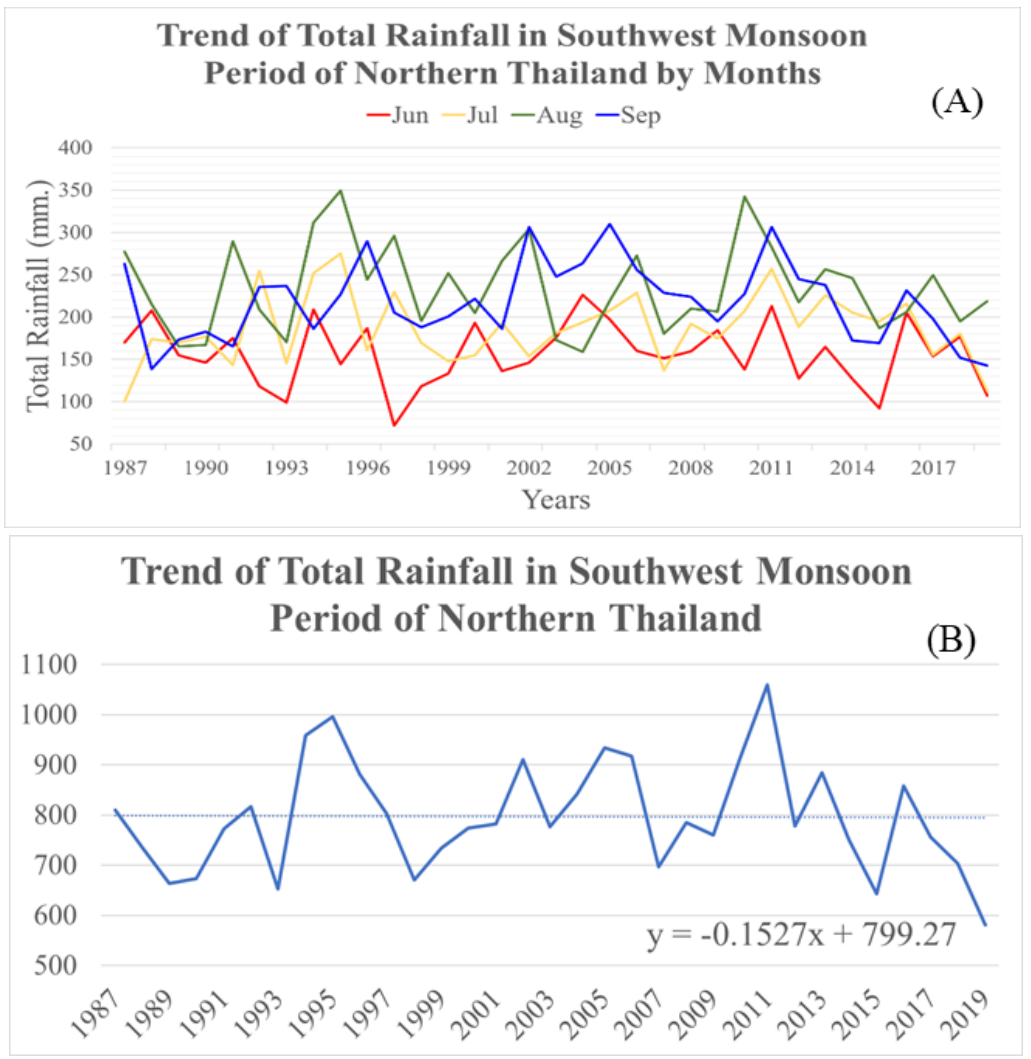

Figure 3 (A) Trend of total rainfall in SW period of Northern Thailand by months $(B)$ Trend of total rainfall in SW monsoon period of Northern Thailand

\section{Discussion and Conclusion}

There was no pattern for total of rainfall distribution and agricultural drought characteristics distribution. The total rainfall trend was illustrated that the rainfall trend fluctuated, and when focused on by months, the trend hit the peak at August then, gradually decreased. The agricultural drought was presented by total rainfall maps and $\mathrm{GMI}_{\mathrm{sw}}$ in 1989, 1990, 1993, 1997, 1998, 1999, 2007, 2015, 2018 and 2019. Moreover, Thailand had to face with El Nino effect in 1987, 1991, 1992, 1993, 1997, 2002, 2014, 2015, 2018 and 2019 which caused Thailand to have high temperature than normal and the rainfall was lower than usual (Australian Government Bureau of Meteorology, 2020). The agricultural drought analysis by GMIsw can be a prove that Northern Thailand faced with abnormal situation, which all authorities and people have to be awareness and plan to solve this situation. For the weakness of this study is that the author focused on just the total of rainfall in Northern Thailand and analyzing of agricultural drought by just Generalized Monsoon Index $\left(\mathrm{GMI}_{\mathrm{sw}}\right)$ method. This drawback might represent that it might be not enough to analyse the drought in Northern Thailand. However, there are many methods to analyse drought impact such as the standardized Precipitation Index or SPI method and the meteorological Drought Index or D method. Moreover, there are several different data which can be used to analyse the drought impact such as topography pattern, Slope pattern, human activities, relative humidity, Land use pattern, etc. 

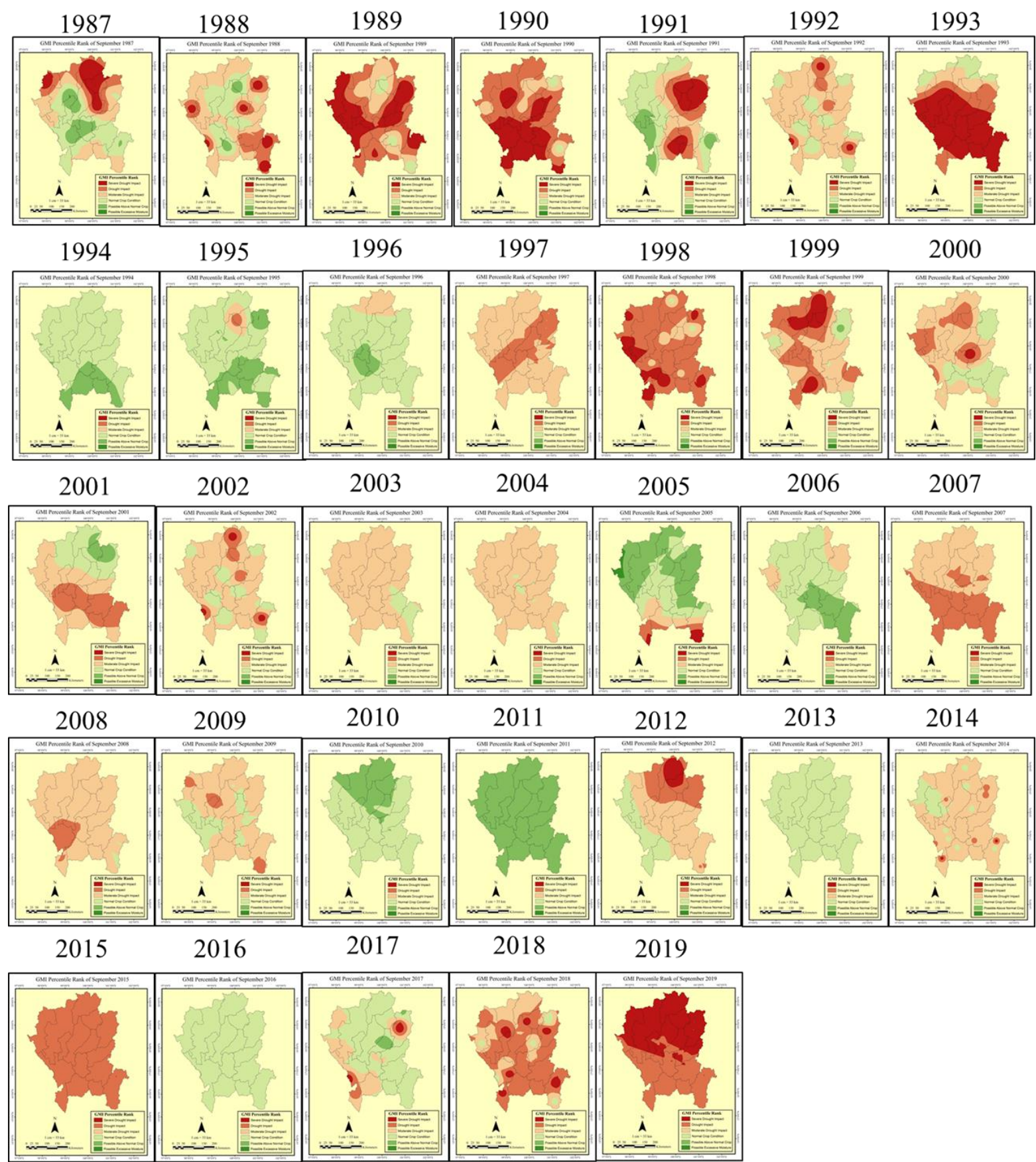

\begin{tabular}{ccl}
\hline GMI $_{\mathrm{pct}}$ & Level of drought & \multicolumn{1}{c}{ Plants health } \\
\hline $0-20$ & 6 & severe drought impact and possible crop failure \\
\hline $21-30$ & 5 & drought impact on crops \\
\hline $31-40$ & 4 & moderate drought impact on crops \\
\hline $41-60$ & 3 & normal crops condition \\
\hline $61-90$ & 2 & possible above normal crops \\
\hline $91-100$ & 1 & possible excessive moisture \\
\hline
\end{tabular}

Figure 4: Distribution of GMI Percentile rank after Southwest Monsoon period of 1987 to 2019 in Northern, Thailand 


\section{Reference}

Achutuni, V.R., Steyaert, L.T., and Sakamoto., C.M. (1982). Agroclimatic assessment methods for drought flood shortages in South and Southeast Asia-Test and evaluation. Final Report to the Agency for International Development U.S. of Foreing DisasterAssistance, Washington, D.C.

Australian Government Bureau of Meteorology. (2020). ENSO Outlook. Retrieved 26 January 2020 from http://www.bom.gov.au/climate/enso/outlook/\#tabs=ENSO-Outlook-history

CARE/HRIP. (1994). CARE Highland Resources Integration Project, Phase 111 Implementation 1992-94. Final Evaluation Report. Bangkok: CARE/International Thailand.

CTN News. (2019). Thais Warned to Prepare for Worst Drought in 40 Years. Chiang Rai Times. Retrieved 26 January 2020 from https://www.chiangraitimes.com/thailand-national-news/northenthailand/thais-warned-to-prepare-for-worst-drought-in-40-years/

Luedi, J. (2016). Extreme drought threatens Thailand's political stability. Retrieved 26 August 2016 from http://globalriskinsights.com/2016/01/extreme-drought-threatens-thailands-political-stability/

Office of Agricultural Economics. (2019). Agricultural Statistics of Thailand 2018. Bangkok: Ministry of Agriculture and Cooperatives. Retrieved from https://www.oae.go.th/assets/portals/1/files/jounal/2562/yearbook2561.pdf

Office of national economic and social development council. (2020). Northern development plan 2017-2022. Retrieved from https://www.nesdb.go.th/ewt_dl_link.php?nid=7528

Subramanya, K., 2008. Engineering Hydrology. New Delhi: Yata McGraw-Hill.

Thai meteorological department. (2012). Generalized Monsoon Index. In THE ASSESSMENT OF RAINFALL IMPACT ON CROPS IN THAILAND Vol. 10 No. 3. Bangkok: Thai meteorological department. Retrieved from

https://www.tmd.go.th/programs\%5Cuploads\%5Crainaffect\%5CAUGUST(Total).pdf

Thai meteorological department. (2019). Climatology of Thailand. Retrieved 24 March 2017 from https://www.tmd.go.th/info/info.php?FileID=22

Wichitarapongsakun, P. Sarina, C., Klomjeka, P., Chuenchooklinb, S. (2016). Rainfall prediction and meteorological drought analysis in the Sakae Krang River basin of Thailand. Agriculture and Natural Resources, 50(6), 490-498. DOI: https://doi.org/10.1016/j.anres.2016.05.003 